\title{
Some coincidence point theorems in ordered metric spaces via $w$-distances
}

CHIRASAK MONGKOLKEHA ${ }^{1}$ and YeOL JE $\mathrm{CHO}^{2,3}$

\begin{abstract}
.
The purpose of this paper is to prove some existence theorems of coincidence points for generalized weak contractions in the setting of partially ordered sets with a metric via $w$-distances and give some example to illustrate our main results.
\end{abstract}

Acknowledgements. The author would like to thank the Kasetsart University Research and Development Institute (KURDI) for financial support.

\section{REFERENCES}

[1] Alber, Ya. I. and Guerre-Delabriere, S., Principle of weakly contractive maps in Hilbert spaces, in: New Results in Operator Theory and its Applications, vol. 98, Birkhauser, Basel, 1997, pp. 7-22

[2] Ćirić, Lb., Abbas, M., Damjanovic, B. and Saadati, R., Common fuzzy fixed point theorems in ordered metric spaces, Math. Comput. Model., 53 (2011), 1737-1741

[3] Dutta, P. N. and Choudhury, B. S., A generalisation of contraction principle in metric spaces, Fixed Point Theory Appl., 2008, Article ID 406368, 8 pp.

[4] Gnana-Bhaskar, T. and Lakshmikantham, V., Fixed point theorems in partially ordered metric spaces and applications, Nonlinear Anal., 65 (2006), 1379-1393

[5] Imdad, M. and Rouzkard, F., Fixed point theorems in ordered metric spaces via w-distances, Fixed Point Theory Appl., 2012, 2012:222

[6] Jungck, G., Compatible mappings and common fixed Points, Internat. J. Math. Math. Sci., 9 (1986), 771-779

[7] Kada, O., Suzuki, T. and Takahashi, W., Nonconvex minimization theorems and fixed point theorems in complete metric spaces, Math. Japon., 44 (1996), 381-391

[8] Khan, M. S., Swaleh, M. and Sessa, S. Fixed point theorems by altering distances between the points, Bull. Aust. Math. Soc., 30 (1984), 1-9

[9] Rhoades, B. E., Some theorems on weakly contractive maps, Nonlinear Anal., 47 (2001), 2683-2693

[10] Roshan, J. R., Parvaneh, V. and Altun, I., Some coincidence point results in ordered b-metric spaces and applications in a system of integral equations, Appl. Math. Comput., 226 (2014), 725-737

[11] Takahashi, W., Existence theorems generalizing fixed point theorems for multivalued mappings, in Fixed Point Theory and Applications, Marseille, 1989, Pitman Res. Notes Math. Ser., 252 Longman Sci. Tech., Harlow, 1991, pp. 39-406

[12] Takahashi, W., Nonlinear Functional Analysis "Fixed Point Theory and its Applications", Yokahama Publishers, Yokahama, Japan, 2000

${ }^{1}$ Department of Mathematics Statistics and Computer Sciences,

FACULTy OF LiBERAL ARTS AND SCIENCE

KASETSART UNIVERSITY, KAMPHAENG-SAEN CAMPUS, NAKHONPATHOM 73140, THAilAND

E-mail address: faascsmeku.ac.th

Received: 20.08.2017; In revised form: 13.06.2018; Accepted: 20.06.2018

2010 Mathematics Subject Classification. 54H25; 47H10.

Key words and phrases. compatible, coincidence points, generalized weak contraction, monotone property, wdistances.

Corresponding author: Yeol Je Cho; yjcho@gnu.ac.kr 
2 School of Mathematical Sciences

UNIVERSITY OF ELECTRONIC SCIENCE AND TECHNOLOGY OF CHINA

Chengdu, Sichuan 611731, P. R. China

${ }^{3}$ Department of Mathematics Education

GYEONGSANG NATIONAL UNIVERSITY, JiNJU 52828, KOREA.

E-mail address: y jcho@gnu.ac.kr 